\title{
IL I3 gene polymorphisms modify the effect of exposure to tobacco smoke on persistent wheeze and asthma in childhood, a longitudinal study
}

\author{
Alireza Sadeghnejad*1, Wilfried Karmaus*2, S Hasan Arshad ${ }^{3,4}$, \\ Ramesh Kurukulaaratchy ${ }^{3,4}$, Marianne Huebner ${ }^{5}$ and Susan Ewart ${ }^{6}$
}

\begin{abstract}
Address: ${ }^{1}$ Center for Human Genomics, Wake Forest University School of Medicine, Winston-Salem, North Carolina, USA, ${ }^{2}$ Department of Epidemiology and Biostatistics, University of South Carolina, Columbia, South Carolina, USA, ${ }^{3}$ The David Hide Asthma \& Allergy Research Centre, St. Mary's Hospital, Isle of Wight, UK, ${ }^{4}$ IIR Research Division, School of Medicine, University of Southampton, Southampton, UK, ${ }^{5}$ Department of Statistics and Probability, Michigan State University, East Lansing, Michigan, USA and ${ }^{6}$ Department of Large Animal Clinical Sciences, Michigan State University, East Lansing, Michigan, USA
\end{abstract}

Email: Alireza Sadeghnejad* - asadeghn@wfubmc.edu; Wilfried Karmaus* - karmaus@sc.edu; S Hasan Arshad - S.H.Arshad@soton.ac.uk; Ramesh Kurukulaaratchy - ramesh@jk7771.fsnet.co.uk; Marianne Huebner - huebner@msu.edu; Susan Ewart - ewart@cvm.msu.edu

* Corresponding authors

Published: 10 January 2008

Respiratory Research 2008, 9:2 doi:10.1186/1465-9921-9-2
Received: 29 May 2007

Accepted: 10 January 2008

This article is available from: http://respiratory-research.com/content/9/I/2

(C) 2008 Sadeghnejad et al; licensee BioMed Central Ltd.

This is an Open Access article distributed under the terms of the Creative Commons Attribution License (http://creativecommons.org/licenses/by/2.0), which permits unrestricted use, distribution, and reproduction in any medium, provided the original work is properly cited.

\section{Abstract}

Background: Tobacco smoke and genetic susceptibility are risk factors for asthma and wheezing. The aim of this study was to investigate whether there is a combined effect of interleukin- 13 gene (ILI3) polymorphisms and tobacco smoke on persistent childhood wheezing and asthma.

Methods: In the Isle of Wight birth cohort (UK, 1989-1999), five ILI3 single nucleotide polymorphisms (SNPs): rsI800925 (-IIII2C/T), rs2066960, rsI295686, rs2054I (RI30Q) and rs 1295685 were genotyped. Parents were asked whether their children had wheezed in the last 12 months at ages I, 2, 4 and 10 years. Children who reported wheeze in the first 4 years of life and also had wheezing at age 10 were classified as early-onset persistent wheeze phenotype; non-wheezers never wheezed up to age 10 . Persistent asthma was defined as having a diagnosis of asthma both during the first four years of life and at age 10. Logistic regression methods were used to analyze data on 79 I children with complete information. Potential confounders were gender, birth weight, duration of breast feeding, and household cat or dog present during pregnancy.

Results: Maternal smoking during pregnancy was associated with early-onset persistent wheeze (OR $2.93, p<0.000 \mathrm{I}$ ); polymorphisms in ILI3 were not (OR I.I5, $p=0.60$ for the common haplotype pair). However, the effect of maternal smoking during pregnancy was stronger in children with the common ILI 3 haplotype pair compared to those without it (OR 5.58 and OR I.29, respectively; $p$ for interaction $=0.014)$. Single SNP analysis revealed a similar statistical significance for $r s 2054 \mathrm{I}(p$ for interaction $=0.02$ ). Comparable results were observed for persistent childhood asthma ( $p$ for interaction $=0.03$ ).

Conclusion: This is the first report that shows a combined effect of in utero exposure to smoking and ILI3 on asthma phenotypes in childhood. The results emphasize that genetic studies need to take environmental exposures into account, since they may explain contradictory findings. 


\section{Background}

It has been suggested that the increased prevalence of asthma-related phenotypes over the last three decades is due to exposure to environmental factors [1]. Among such exposures, environmental tobacco smoke is regarded as an important risk factor for asthma-related phenotypes $[2,3]$. In particular, an effect of maternal smoking during pregnancy on the development of asthma in offspring has been proposed [2,4-7]. Parental smoking has also been reported to be associated with markers of atopy, such as serum immunoglobulin E (IgE) levels [8]. Interleukin-13 (IL-13) is an important cytokine involved in the IgE pathway and pathogenesis of asthma [9]. Pulmonary expression of IL13 is reported to produce inflammation, mucus hypersecretion, subepithelial fibrosis and eotaxin production [10]. It has been reported that exposure to tobacco smoke during pregnancy was associated with a significantly higher production of IL-13 [11,12]. These observations suggest that part of the effect of exposure to tobacco on asthma-related phenotypes might be through cytokines.

Researchers have speculated that individuals may vary in genetic susceptibility to the physiologic and cellular response to cigarette smoke exposure and a few studies have examined gene-smoking interactions for asthma [1316]. Wang et al. observed that an interaction between maternal smoking and the $\beta_{2}$ adrenergic receptor gene was associated with asthma in offspring [15]. Kabesch et al. demonstrated an interaction between smoking and glutathione $S$ transferase deficiency on asthma [16]. In two genome-wide screens, interactions between passive tobacco exposure and chromosome $5 \mathrm{q}$, the region in which the IL-13 gene (IL13) is located, have been reported for asthma phenotypes $[13,14]$. Recently we reported an interaction of smoking and the IL13 single nucleotide polymorphism (SNP) rs1800925 related to reduced lung function in long term tobacco smokers [17].

Compared to wild type IL-13, a non-synonymous polymorphism in the IL13 gene, rs20541 (+2044 G/A, R130Q), has been shown to be associated with more active IL-13 [18]. It has also been reported that the rs1800925 $(-1112 \mathrm{C} / \mathrm{T})$ polymorphism resulted in enhanced promoter activity [19]. In spite of the importance of IL-13 in asthma $[9,11,12]$, some studies failed to show an association between IL13 polymorphisms and asthma phenotypes $[20,21]$, possibly because of different prevalence of environmental risk factors such as tobacco smoke exposure.

Because of the high prevalence (25-30\%) of smoking among women of reproductive age [22] there is a need to investigate its possible role in the development of asthmarelated phenotypes. In prior assessments of the Isle of
Wight birth cohort study, we have shown that children with early-onset persistent wheeze have the highest amount of morbidity in association with atopic sensitization, hospital admission and steroid therapy for asthma [23] To our knowledge there is no investigation as to whether the adverse effect of maternal smoking on asthma may result from an interaction between exposure to tobacco smoke and cytokine regulating genes. In the current work we test the hypothesis that an interaction between maternal smoking during pregnancy and the IL13 gene is associated with increased risk of early-onset persistent wheeze and persistent childhood asthma in the Isle of Wight birth cohort.

\section{Methods}

\section{Population and data}

The local Research Ethics Committee approved the study of children born and enrolled $(\mathrm{n}=1,456)$ between January 1,1989, and February 28, 1990, on the Isle of Wight, United Kingdom. Written consent was obtained and children were followed up at the ages of 1, 2, 4 and 10 years. The island is close to the British mainland, semi-rural, with no heavy industry. The population is 99\% Caucasian.

At birth, weight was obtained from hospital records and parents were asked about their age and exposures during pregnancy. At subsequent follow-ups, a questionnaire was administered seeking information on exposure to tobacco smoke, breast feeding, and wheezing in the cohort children.

\section{Exposure to tobacco smoke}

Information on tobacco smoking by mothers (during pregnancy and later), fathers, or any other individual inside the home was recorded at recruitment and updated at each follow-up. Exposures to environmental tobacco smoke (ETS) in the household and maternal smoking during pregnancy were combined and classified into three groups. When mothers did not smoke during pregnancy and there was no exposure to household ETS in children up to the age of 10, children were categorized as "ETS-0". When mothers did not smoke during pregnancy, but household members smoked within the home at some point up to the child's age of 10 years, the exposure status was categorized as "ETS-1". When mothers smoked during pregnancy and the children were also exposed to household ETS at some point up to the age of 10, the exposure was categorized as "ETS-2". None of the children had mothers who smoked during pregnancy but no exposure to household tobacco smoke after birth.

\section{Definition of wheeze phenotypes and persistent childhood asthma}

At each of the four follow-ups at ages 1, 2, 4, and 10 years, "current wheeze" was recorded if wheezing occurred on at 
least one occasion in the previous 12 months. Parents were also asked whether the child had any wheeze episode between ages 4 and 10. Children were then categorized into wheezing phenotypes as follows: non-wheezers never wheezed in the first decade of life, early-onset persistent wheezers had wheezed in the first 4 years of life and still wheezed at age 10, while late-onset persistent wheezers had wheezing onset after 4 years of age and still wheezed at age 10. Early transient wheezers began wheezing in the first 4 years but stopped at least 12 months before age 10 . Details on wheeze phenotypes from 1 to 10 years of this cohort have been reported previously [23].

Asthma was based on investigator diagnosis of asthma and has been described in previous reports of this cohort [24]. Persistent childhood asthma was defined as having asthma diagnosis at age 10 in addition of at least one asthma diagnosis in the first four years of life, the control group included children with no asthma diagnosis at any time point, case-cohort analysis.

\section{DNA isolation and ILI 3 genotyping}

Anticoagulated whole blood samples were obtained at the 10 -year interview and stored frozen $(\mathrm{n}=921)$. Genomic DNA was isolated from these samples using QIAamp DNA Blood Kits (Qiagen, Valencia, CA) or the ABI PRISM $^{\mathrm{TM}} 6100$ Nucleic Acid PrepStation (Applied Biosystems, Foster City, CA). Polymorphisms in the IL13 gene were examined using the SNPper and Applied Biosystems databases [25]. Genotyping was conducted by fluorogenic 5 ' nuclease chemistry PCR using Assays on Demands kits cycled on a 7900HT Sequence Detection System (Applied Biosystems, Foster City, CA), or biotin-streptavidin-based pyrosequencing performed on PSQ-96 instrumentation (Biotage AB, Uppsala, Sweden).

Five SNPs from the IL13 gene were used in this study: rs1800925 in the 5 ' promoter region, rs2066960 in intron 1 , rs1295686 in intron 3 at the intron/exon boundary, rs20541 in exon 4 and rs 1295685 in the 3 ' untranslated region (UTR) of exon 4 . The rs20541 is a coding variant with the common allele $(\mathrm{G})$ coding for arginine and the minor allele (A) encoding glutamine at amino acid 144 . Because IL13 is a small gene $(2.9 \mathrm{~kb})$, only a few SNPs were needed for a reasonable assessment of genetic associations. The SNPs in this report build upon the haplotype tagging (ht)-SNPs indicated by Tarazona-Santos and Tishkoff in a European population [26] and they include those most commonly examined for association with asthma and related phenotypes in other previous studies [27-31].

\section{Statistical analysis}

Each SNP was tested for Hardy-Weinberg equilibrium using Haploview 3.2 software [32]. Estimates of linkage disequilibrium (LD) between SNPs were calculated using $D^{\prime}$ and $r^{2}$ [33]. PHASE 2.0.2 was employed to build the most likely pair of haplotypes (diplotypes) and their probability for each child [34], using all five SNPs. In the analysis of individual SNPs and haplotype pairs, genotypes with low frequencies were combined $[35,36]$.

Using SAS/STAT ${ }^{\circledR}$ version 9.1, statistical analysis was performed on the data only from children who had complete information on IL13 genotypes, exposure to tobacco smoke and wheeze phenotypes. Chi-square tests were used to compare the sample used in the analysis with that which was followed up at age 10 . To investigate main effects and interactions between smoke exposures and genetic polymorphisms for the wheeze phenotypes, a multinomial logistic regression analysis (PROC GLIMMIX, SAS) was conducted. For analysis of persistent asthma simple logistic regression (PROC LOGISTICS, SAS) was used.

To evaluate the associations between wheeze phenotypes and other variables of interest, non-wheezers were used as the control group. Persistent childhood asthma was treated as a dichotomous variable (yes, no). Confounders were chosen based on their importance in studying wheeze phenotypes in a prior report of the Isle of Wight cohort [37]. Potential confounders (table 1) were: gender, low birth weight $(<2,500$ grams versus $\geq 2,500$ grams), breast feeding ( $<$ three months and $\geq$ three months), household cat present during pregnancy (yes, no) and household dog present during pregnancy (yes, no).

\section{Results}

Data on IL13 genotypes, exposure to tobacco smoke and wheeze phenotypes were available for 791 children. The percentages of children who wheezed and those who had ETS- 0 were higher in the sample used in the analyses compared to all those who were followed up to age 10 (table 1 ). More than half of the children were exposed to tobacco smoke up to age 10 (23.3\% during and after pregnancy; $31.5 \%$ after pregnancy, table 1$)$.

For IL13 genotypes, all five SNPs were in Hardy-Weinberg equilibrium and three of the SNPs (rs1295686, rs20541 and rs1295685) demonstrated linkage disequilibrium based on $D^{\prime}(\geq 0.95)$ and $r^{2}(\geq 0.89$, Figure 1$)$. Therefore, haplotypes were inferred using rs20541 from this block and the other two SNPs (rs1800925 and rs2066960). Due to the limited number of children homozygous for minor alleles at all SNPs (less than 5\%, table 2), minor allele homozygous and heterozygous genotypes were grouped together. Among haplotype pairs, CCG/CCG (for SNPs ordered rs1800925, rs2066960, rs20541) had the highest frequency $(0.48$, table 3$)$. The estimated probability for CCG/CCG as the best pair was 1.0 in $99 \%$ of children and 
Table I: Comparison of children with a follow-up at age 10 and the subset used in the analysis

\begin{tabular}{|c|c|c|c|c|}
\hline & & Numbers at age 10 (\%) & Numbers used in the analysis (\%) & $\chi^{2} p$ value \\
\hline Variable & Total & 1,373 & 791 & \\
\hline \multirow[t]{5}{*}{ Wheeze Phenotype } & Early-onset persistent* & $139(12.7)$ & $105(13.3)$ & 0.60 \\
\hline & Late-onset persistent $\dagger$ & $81(7.4)$ & $70(8.9)$ & \\
\hline & Early transient $\ddagger$ & $259(23.6)$ & $190(23.9)$ & \\
\hline & Non-wheezer§ & $617(56.3)$ & $426(53.9)$ & \\
\hline & Missing & 277 & 0 & \\
\hline \multirow[t]{3}{*}{ Birth weight } & $\geq 2500$ grams & $1287(96.3)$ & $736(96.0)$ & 0.75 \\
\hline & $<2500$ grams & $49(3.7)$ & $31(4.0)$ & \\
\hline & Missing & 37 & 24 & \\
\hline \multirow[t]{4}{*}{ Exposure to tobacco smoke } & ETS-0 & $617(45.2)$ & $381(48.2)$ & 0.22 \\
\hline & ETS-I & $430(31.5)$ & $249(31.5)$ & \\
\hline & ETS-2 & $319(23.3)$ & $161(20.3)$ & \\
\hline & Missing & 7 & 0 & \\
\hline \multirow[t]{2}{*}{ Gender } & Girl Boy & $676(49.2)$ & $388(49.3)$ & 0.98 \\
\hline & & $697(50.8)$ & $399(50.7)$ & \\
\hline \multirow[t]{3}{*}{ Breast fed } & $\geq 3$ months & $470(4 \mid .7)$ & $322(42.8)$ & 0.67 \\
\hline & $<3$ months & $657(58.3)$ & $430(57.2)$ & \\
\hline & Missing & 246 & 39 & \\
\hline \multirow[t]{3}{*}{ Household cat during pregnancy } & Yes & $453(33.2)$ & $269(34.0)$ & 0.68 \\
\hline & No & $912(66.8)$ & $521(66.0)$ & \\
\hline & Missing & 8 & i & \\
\hline \multirow[t]{3}{*}{ Household dog during pregnancy } & Yes & 395 (28.9) & $240(30.4)$ & 0.48 \\
\hline & No & 970 (7I.1) & $550(69.6)$ & \\
\hline & Missing & 8 & I & \\
\hline
\end{tabular}

* Onset of wheeze in the first 4 years, still present at age 10.

$\dagger$ Onset of wheeze after age 4 years, still present at age 10.

$\ddagger$ Wheeze only in the first 4 years.

$\S$ No wheeze up to age 10.

ETS-0, mothers did not smoke during pregnancy and children not exposed to household ETS; ETS-I, mothers did not smoke during pregnancy, but children were exposed to household ETS; ETS-2, mothers smoked during pregnancy and children were exposed to household ETS

at least 0.89 in the rest (results not shown). All other haplotype pairs had frequencies between 0.019-0.155. In addition, there were probabilities as low as 0.5 that were identified as the best pair for haplotype pairs other than CCG/CCG. Thus, haplotype pairs other than CCG/CCG were combined $[35,36]$.

To determine the associations of IL13, exposure to tobacco smoke and their combination on wheeze phenotypes, we conducted multinomial logistic regression. Crude analysis showed that, with the exception of rs2066960 with early-transient wheeze, genotypes of individual SNPs or haplotype pairs were not associated with early-onset persistent wheeze (table 4, reference:nonwheezers) or other wheeze phenotypes; maternal smoking during pregnancy (ETS-2) was associated with earlyonset persistent wheeze $(\mathrm{p}<0.0001$, table 4$)$.

In a stratified analysis, the combined effect of IL13 genotypes and exposure to tobacco smoke on early-onset persistent wheeze was assessed. In the strata with common (homozygous major allele)IL13 genotypes, the effects of maternal smoking during pregnancy on early-onset persistent wheeze were significant (figure 2). In particular, figure 2 shows for the five SNPs and for the IL13 haplotype that common genotypes were not related to a higher prevalence of wheezing in non-smoke exposed children (white bars). However, under the condition of prenatal smoke exposure, children with common genotypes showed a statistically increased risk of early-onset persistent wheezing (black bars). This combined effect was not found for children who had minor homozygous or heterozygous genotypes.

Table 5 shows a model to evaluate the statistical interaction of CCG/CCG and smoking. For early-onset persistent wheeze, the interaction term between ETS-2 and CCG/ CCG showed statistical significance $(p<0.014$, table 5$)$. For this combined effect the two different ORs $(\mathrm{OR}=2.59$ and $\mathrm{OR}=5.89$ ) are calculated based on two different scenarios. In the first case $(\mathrm{OR}=2.59)$, children exposed to maternal smoking during pregnancy are the reference and the effect of the gene is added to this equation, thus, given this reference, the effect of maternal smoking during preg- 


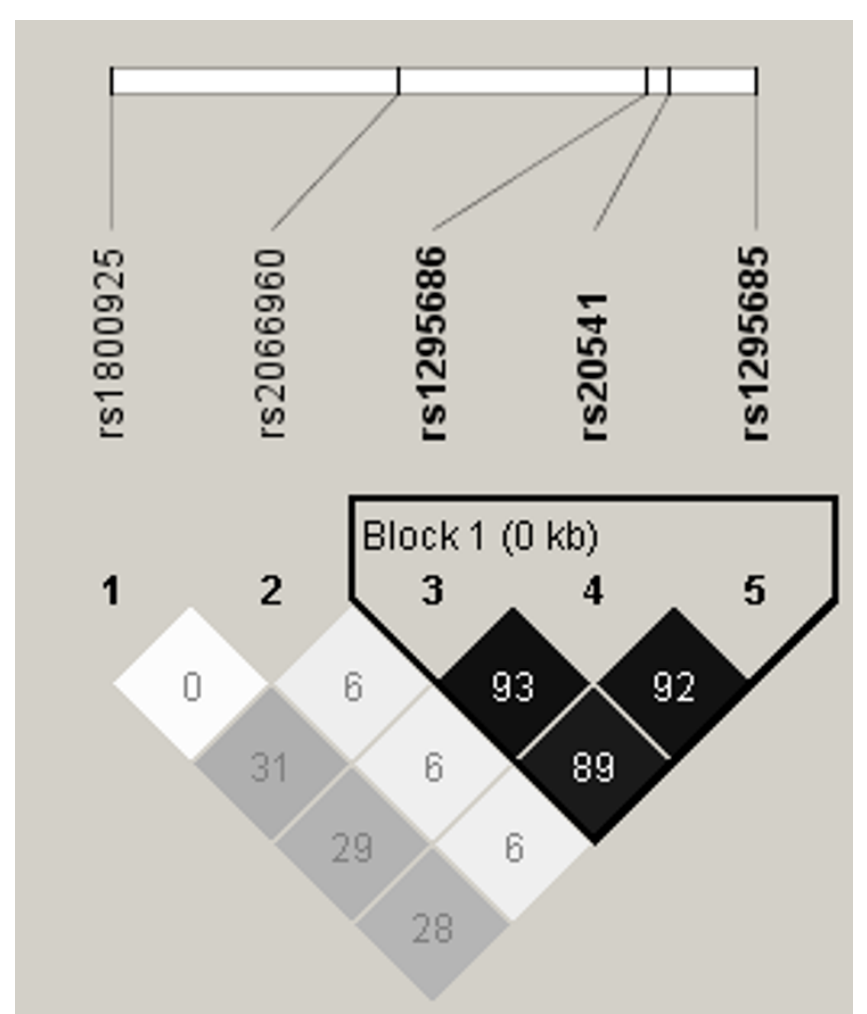

\section{Figure I}

Using the Haploview program [32], three single nucleotide polymorphisms of the interleukin I 3 gene appeared to be in a block. $r^{2}$, a pair wise linkage disequilibrium determinant [33], is shown.

nancy is eliminated from the equation. In the second case (OR = 5.89), children with the CCG/CCG haplotype pair are the reference and maternal smoking during pregnancy is introduced to this setting. In addition to the haplotype analysis, single SNP analysis revealed a significant interaction term between rs20451 (GG versus GA+AA) and ETS2 on early-onset persistent wheeze ( $p$ for interaction < 0.020, data not shown).

To determine the effect of minor haplotype pairs (frequency $=0.087$, table 3 ), the analyses were repeated by excluding this group and results did not change significantly (data not shown).

When analyzing asthma, 68 subjects had persistent asthma. The control group were 533 subjects who did not have any asthma diagnosis during the first decade of life. When analyzing asthma instead of wheezing, the interaction between ETS-2 and IL13 haplotype pairs was statistically significant ( $\mathrm{p}=0.03$ ) for persistent asthma as it was for persistent wheeze. Children with a CCG/CCG haplotype pair had an OR of 5.57 (95\% CI 2.13 to 14.63, p = $0.0005)$ for ETS-2 on persistent asthma. For subjects with
Table 2: Genotypes for ILI3 single nucleotide polymorphisms (SNPs)

\begin{tabular}{|c|c|c|c|c|}
\hline SNP & Position (bp) & Location & Genotype & Frequency (\%) \\
\hline \multirow{4}{*}{$\begin{array}{l}\mathrm{rs} / 800925 \\
(-I|I| 2 C / T)\end{array}$} & $132,020,708$ & Promoter & $\mathrm{CC}$ & $577(63.6)$ \\
\hline & & & $\mathrm{CT}$ & $295(32.5)$ \\
\hline & & & $\mathrm{TT}$ & $35(3.9)$ \\
\hline & & & Total & $907(100.0)$ \\
\hline \multirow[t]{4}{*}{ rs2066960 } & $132,022,334$ & Intron I & $\mathrm{CC}$ & $729(81.5)$ \\
\hline & & & $A C$ & $157(17.6)$ \\
\hline & & & $\mathrm{AA}$ & $8(0.9)$ \\
\hline & & & Total & $894(100.0)$ \\
\hline \multirow[t]{4}{*}{ rsl295686 } & $132,023,742$ & Intron 3 & CC & $483(64.6)$ \\
\hline & & & $\mathrm{CT}$ & $240(32.1)$ \\
\hline & & & $\mathrm{TT}$ & $25(3.3)$ \\
\hline & & & Total & $748(100.0)$ \\
\hline \multirow{4}{*}{$\begin{array}{l}\text { rs2054I } \\
\text { (RI30Q) }\end{array}$} & $132,023,863$ & Exon 4 & GG & $583(64.4)$ \\
\hline & & & GA & $291(32.1)$ \\
\hline & & & $\mathrm{AA}$ & $32(3.5)$ \\
\hline & & & Total & $906(100.0)$ \\
\hline \multirow[t]{4}{*}{ rs|295685 } & $132,024,344$ & Exon 4 & GG & $584(64.5)$ \\
\hline & & & GA & $280(30.9)$ \\
\hline & & & $\mathrm{AA}$ & $4 I(4.5)$ \\
\hline & & & Total & $905(100.0)$ \\
\hline
\end{tabular}

Gene annotation is based on SNPper [25]

ILI 3: interleukin- I 3 gene; $n$, number of samples used in genetic studies; bp, basepairs.

haplotype pairs other than CCG/CCG, the OR was 1.32 ( $95 \%$ CI 0.57 to $3.04, \mathrm{p}=0.587$ ).

Among confounders, the presence of a household cat or dog during pregnancy was protective and male sex was a risk factor for early-onset persistent wheeze (table 5).

\section{Discussion}

This study investigated the combined effect of exposure to tobacco smoke and haplotype pairs of the IL13 gene on wheeze phenotypes in the first decade of life using the data from the Isle of Wight birth cohort. Maternal smoking during pregnancy was associated with early-transient and early-onset persistent wheeze. No independent effect for the IL13 gene was detected. However, common variant of IL13 gene polymorphisms were observed to increase the adverse effect of maternal smoking during pregnancy on early-onset persistent wheeze, the phenotype with the highest morbidity [23]. A similar association was observed for the persistent asthma phenotype. Tobacco smoke exposure after pregnancy did not modify the association of IL13 and wheezing nor asthma.

In this study, the information was available from a subset of children who were followed up at age 10 and who agreed to provide blood for genotyping. Although these children appeared to have slightly $(\sim 3 \%)$ more wheeze 
Table 3: Frequency of haplotypes and haplotype pairs for five single nucleotide polymorphisms (rs I 800925, rs2066960, rs2054I) of ILI3, inferred from genotype data of 912 children

\begin{tabular}{lll}
\hline & & Frequency (SE) \\
\hline Haplotype & CCG & $0.687(0.003)$ \\
& TCA & $0.105(0.003)$ \\
& TCG & $0.067(0.002)$ \\
& CCA & $0.043(0.002)$ \\
& CAG & $0.040(0.003)$ \\
& CAA & $0.027(0.002)$ \\
TAA & $0.020(0.003)$ \\
Haplotype pair(s) & TAG & $0.009(0.002)$ \\
& CCG/CCG & 0.478 \\
& minor haplotypes/minor & 0.451 \\
& haplotypest & 0.071
\end{tabular}

PHASE 2.0.2. was used for this analysis [34].

* This group consists of, with a frequency of:

CCG/TCA, 0.155; CCG/TCG, 0.088; CCG/CCA, 0.055; CCG/CAG,

0.054;

CCG/TAA, 0.043; CCG/CAA, 0.038; CCG/TAG, 0.019;

+ This group consists of, with a frequency of:

TCG/TCA, 0.020; CCA/TCA, 0.012; other haplotypes, $<0.010$

ILI3: interleukin-I3

and less exposure to tobacco smoke in comparison to all children who were followed up at age 10, these differences were not significant. The presence of a selection bias could result in a violation of the Hardy-Weinberg equilibrium and different allele frequencies than other Caucasian populations $[29,38]$. The latter scenario was not present, hence, a selection bias is unlikely.

The wheeze phenotypes were specified at age 10 based on longitudinal records from ages 1, 2, 4 and 10. This strengthens the study as we used longitudinal wheeze phenotypes instead of an outcome measured at a single cross section. To avoid recall bias, the analysis was restricted to children who were seen prospectively with information at all study visits [23]. Previously, we have shown that a preceding diagnosis of asthma was less likely to produce biased reports in later follow-ups [24].

Information on individual SNPs was used and the most likely pairs of haplotypes were estimated from genotype data. We demonstrated a significant association between exposure to maternal smoking during pregnancy and early-onset persistent wheeze when children had the common variant for each individual SNP as well as haplotype pairs.

One motivation for using haplotype pairs was the consistent pattern observed for the combined effect of ETS- 2 and all markers (individual SNPs and haplotype pairs) on early-onset persistent wheeze (Figure 2). Additionally, it has been suggested, specifically for IL13 [31], that haplotype analysis could confer more information than individual marker analysis [39,40]. Haplotype pair analysis may misclassify genotypes when parents' genetic information is not available (ambiguous phase). However, the probability of having CCG/CCG, the major haplotype pair, was 1.00 in 429 out of 435 children with this genotype (the probability for the other 6 children was 0.89 ). The distribution of the data, with respect to minor haplotypes, did not allow testing for their interactions with tobacco smoke exposure. However, when children homozygous for minor haplotypes (frequency $=0.071$, table 3 ) were removed from the analysis, the results did not change substantially.

Previous studies have shown an increased risk of asthma in children who were exposed to tobacco during pregnancy [3]. In a prior examination of this cohort, a possible association between exposures during pregnancy and early-onset persistent wheeze was suggested [37]. Additionally, several studies have suggested a gene-environment interaction for the effect of tobacco smoke exposure and

Table 4: Unadjusted Odds Ratios, multinomial logistic regression, for covariates on wheeze phenotypes

\begin{tabular}{|c|c|c|c|}
\hline & Early-transient & Early-onset persistent & Late-onset \\
\hline Covariate & OR, p-value & OR, p-value & OR, p-value \\
\hline rs I800925, CT-TT vs CC & $0.99,0.971$ & $0.98,0.928$ & $0.91,0.743$ \\
\hline rs2066960, CA-AA vs CC & $1.61,0.032$ & I.36, 0.273 & $1.24,0.524$ \\
\hline rs I295686, CT-TT vs CC & $1.02,0.922$ & I.12. 0.642 & $1.02,0.937$ \\
\hline rs2054I, GA-AA vs GG & $1.17,0.393$ & $1.12,0.614$ & $1.55,0.096$ \\
\hline rs I 295685, GG vs GA-AA & $1.16,0.411$ & $1.15,0.535$ & $1.51,0.116$ \\
\hline others vs CCG/CCG & $1.10,0.592$ & $0.93,0.729$ & $1.10,0.709$ \\
\hline ETS-2 vs ETS-0 & $1.70,0.022$ & $2.93,<0.0001$ & $0.57,0.173$ \\
\hline ETS-I vs ETS-0 & $1.57,0.023$ & $1.86,0.018$ & $0.61,0.861$ \\
\hline
\end{tabular}

$\ddagger$ The reference was the group who never report wheeze up to age $10(n=426)$.

CCG/CCG is the most common haplotype pair constructed based on rs 1800925 , rs2066960 and rs2054I, using PHASE 2.0.2 software [34]. ETS-0, mothers did not smoke during pregnancy and children not exposed to household ETS; ETS-I, mothers did not smoke during pregnancy, but children were exposed to household ETS; ETS-2, mothers smoked during pregnancy and children were exposed to household ETS 


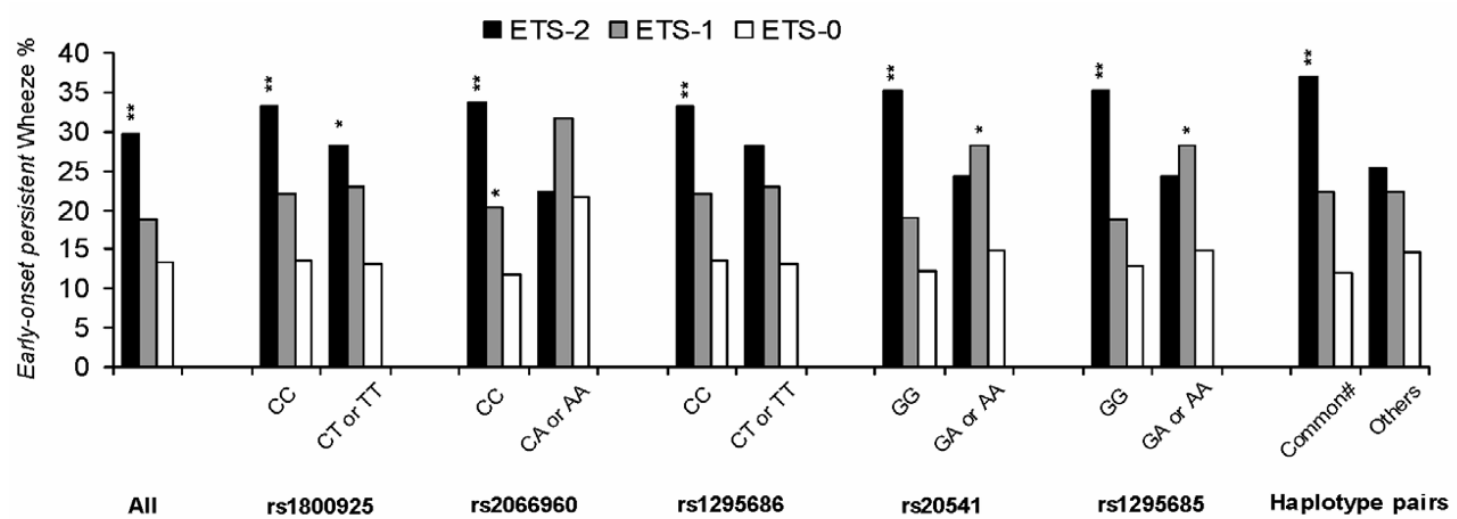

Figure 2

The vertical axis is the percentage of early-onset persistent wheezers divided by the sum of early-onset persistent wheezers and non-wheezers $(\mathbf{n}=\mathbf{7 9}$ I). For each genotype strata, reference was ETS-0. $*, p$ value $<0.05$; $* *, p$ value $<$ 0.00I. ETS-0, mothers did not smoke during pregnancy and children were not exposed to household ETS; ETS-I, mothers did not smoke during pregnancy, but children were exposed to household ETS; ETS-2, mothers smoked during pregnancy and children were exposed to household ETS. SNP, single nucleotide polymorphism; rs I 800925, rs2066960, rs I 295686, rs2054I and rs I 295686 are five SNPs within the interleukin I 3 gene. SNPs rs I295686, rs2054I, and rs I 295686 were in a block. Therefore haplotype analysis was based on SNPs rs 1800925, rs2066960, and rs2054I. \# The most common haplotype pair, CCG/CCG, constructed based on SNPs rs 1800925, rs2066960, and rs2054I, using PHASE 2.0.2 software [34].

asthma phenotypes $[13,14,16]$. Specifically, in two genome-wide screens, Colilla et al and Meyers et al reported that exposure to tobacco modifies the linkage between $5 \mathrm{q}$, the region containing IL13, and asthma phenotypes $[13,14]$. The current study demonstrates a scenario in which a gene modifies the effect of tobacco smoke exposure during pregnancy but not after, thus, time of the exposure may be of critical importance in gene-environment interaction studies. The finding of an interaction between IL13 and ETS in the present study suggests that negative reports for the effect of a candidate gene for IL13 and asthma [20,21], could be explained by a failure to take into account environmental exposures. It is therefore of utmost importance, for genetic studies, to describe environmental exposures in the target population.

Most of the previous studies, including a report on the Isle of Wight cohort [41], suggest that the minor alleles of IL13 SNPs rs20541 (R130Q) and rs1800925 (-1112C/T) are associated with increased adverse effects [10,17-19,42]. In the current study we observed that children who had the common genotype for IL13 polymorphisms (haplotype pairs or SNP rs20541) have increased risk of early onset persistent wheeze and persistent childhood asthma in relation to maternal smoking during pregnancy.

Our finding for common IL13 variants to be a risk factor when mothers smoked during pregnancy is unexpected. Nevertheless, the observed association is statistically significant and cannot be explained by chance $(\mathrm{p}=0.014)$.
Additionally, we see a constant pattern for the effect of smoking across the SNPs and their haplotypes. This latter observation also suggests that it is less likely that the findings are due to a random effect. An unexpected finding for the effect of SNP rs20541 alleles on persistent wheeze is not scientifically untenable as the interplay between genes and environment is complex. Similar discrepancy has been shown for CD14, which turned out to be an interesting gene-environment interaction [43].

It has been suggested that tobacco smoke increases IL-13 and there are some reports on the combined effects of IL13 polymorphisms or other genetic variants in the IL13 region on asthma-related outcomes [11-14,44].

Liu et al. reported a synergistic effect of smoking and IL13 promoter polymorphism on the level of serum IgE [44], and genome-wide analyses have suggested a gene-environment interaction for the effect of tobacco exposure on asthma $[13,14]$. Noakes and colleagues demonstrated that cord blood cells produce significantly higher levels of IL13 in response to both house dust mite and ovalbumin when newborns are exposed to tobacco smoke during pregnancy [11]. This suggests that prenatal exposure to tobacco elicits immunological effects. In our analysis, the interaction between tobacco exposure and IL13 polymorphisms was present in those who were exposed during and after pregnancy, but was not evident for the group with the same polymorphisms who were exposed only after pregnancy. As there was no group of children that was exposed only during pregnancy, it is not possible to 
Table 5: Adjusted estimates, multinomial logistic regression model, for the effect of smoke exposure and the major haplotype pair (CCG/CCG) $\dagger$ of ILI3 gene on wheeze phenotypes

\begin{tabular}{|c|c|c|c|c|c|c|}
\hline \multirow{2}{*}{$\begin{array}{l}\text { Variable } \\
\text { Boy }\end{array}$} & \multirow{2}{*}{$\frac{\text { Function } \ddagger}{1}$} & \multirow{2}{*}{$\begin{array}{l}\text { estimate } \\
0.52\end{array}$} & \multirow{2}{*}{$\begin{array}{l}P \text { value } \\
0.006\end{array}$} & \multicolumn{3}{|c|}{ Odds ratio \& $95 \% \mathrm{Cl}$} \\
\hline & & & & 1.69 & 1.16 & 2.49 \\
\hline & 2 & 0.64 & 0.009 & 1.90 & 1.18 & 3.06 \\
\hline & 3 & 0.29 & 0.275 & 1.33 & 0.80 & 2.23 \\
\hline \multirow[t]{3}{*}{ Birth weight $<2500 \mathrm{~g}$} & 1 & -1.11 & 0.012 & 0.33 & 0.14 & 0.78 \\
\hline & 2 & -0.10 & 0.887 & 0.91 & 0.24 & 3.49 \\
\hline & 3 & -0.14 & 0.863 & 0.87 & 0.19 & 4.09 \\
\hline \multirow[t]{3}{*}{ Breast feeding $<3$ months } & 1 & -0.03 & 0.170 & 0.97 & 0.93 & 1.01 \\
\hline & 2 & -0.06 & 0.037 & 0.94 & 0.88 & 0.99 \\
\hline & 3 & 0.05 & 0.116 & 1.05 & 0.99 & 1.11 \\
\hline \multirow[t]{3}{*}{ Having a cat during pregnancy } & 1 & -0.06 & 0.776 & 0.94 & 0.64 & 1.40 \\
\hline & 2 & -0.49 & $0.07 I$ & 0.62 & 0.36 & 1.04 \\
\hline & 3 & -0.02 & 0.949 & 0.98 & 0.57 & 1.69 \\
\hline \multirow[t]{3}{*}{ Having a dog during pregnancy } & 1 & 0.00 & 0.980 & 0.99 & 0.67 & 1.49 \\
\hline & 2 & -0.55 & 0.050 & 0.58 & 0.33 & 1.00 \\
\hline & 3 & -0.25 & 0.401 & 0.78 & 0.43 & 1.40 \\
\hline \multirow[t]{3}{*}{ ETS-2 } & 1 & 0.52 & 0.130 & 1.67 & 0.86 & 3.28 \\
\hline & 2 & 0.25 & 0.573 & 1.29 & 0.54 & 3.08 \\
\hline & 3 & -0.76 & 0.245 & 0.47 & 0.13 & 1.68 \\
\hline \multirow[t]{3}{*}{ CCG/CCG } & 1 & -0.06 & 0.849 & 0.95 & 0.54 & 1.67 \\
\hline & 2 & -0.57 & 0.163 & 0.57 & 0.25 & 1.26 \\
\hline & 3 & 0.02 & 0.945 & 1.02 & 0.52 & 2.01 \\
\hline \multirow[t]{3}{*}{$\mathrm{ETS}-2 \times \mathrm{CCG} / \mathrm{CCG}$} & 1 & $¥-0.35$ & 0.491 & 0.66 & 0.28 & 1.54 \\
\hline & 2 & $¥ 1.52$ & 0.014 & 2.59 & 1.04 & 6.44 \\
\hline & 3 & $¥ 0.70$ & 0.409 & 2.06 & 0.45 & 9.33 \\
\hline \multirow[t]{3}{*}{ ETS-I } & 1 & 0.42 & 0.161 & 1.52 & 0.85 & 2.74 \\
\hline & 2 & 0.40 & 0.289 & 1.49 & $0.7 I$ & 3.09 \\
\hline & 3 & 0.16 & 0.687 & 1.17 & 0.54 & 2.52 \\
\hline \multirow[t]{3}{*}{ ETS-I $\times$ CCG/CCG $¥$} & 1 & $¥ 0.25$ & 0.566 & 1.21 & 0.65 & 2.26 \\
\hline & 2 & $¥ 0.48$ & 0.410 & 0.92 & 0.40 & 2.07 \\
\hline & 3 & $¥-0.45$ & 0.459 & 0.65 & 0.24 & 1.76 \\
\hline
\end{tabular}

ETS-0, mothers did not smoke during pregnancy and children not exposed to household ETS; ETS-I, mothers did not smoke during pregnancy, but children were exposed to household ETS; ETS-2, mothers smoked during pregnancy and children were exposed to household ETS.

† The most common haplotype pair, inferred from genotype data of five single nucleotide polymorphisms of interleukin 13 gene, rs 1800925 , rs2066960 and rs2054I, using PHASE 2.0.2 software [34].

‡ correspond to a specific wheeze phenotype: Function I: early-transient $(n=190), 2$ : early-onset persistent $(n=105)$, 3: late-onset $(n=70)$. The reference was the group who never report wheeze up to age $10(n=426)$.

$\times$ Denotes an interaction.

$¥$ For interaction terms, GLIMMIX estimates the Odds Ratio $(95 \% \mathrm{Cl})$ of the combined effect based on the parameter estimate of the main and the interaction effect. For the interaction term, we present the Odds Ratio for two combined effects, but not the statistical significant estimate of the individual interaction term. For example for early-onset persistent wheeze (function 2), the OR for children with the CCG/CCG genotype who had mothers who smoked during pregnancy is exponential $(1.5223+[-0.57])=2.59$. The OR for maternal smoking during pregnancy $(E T S-2=I)$ in children having the CCG/CCG genotype is exponential $(-0.2512+1.5223)=5.89(95 \% \mathrm{Cl}: 2.47,14.1)$. The difference in the combined effects results from different reference groups (no smoking during pregnancy and not the CCG/CCG genotype, respectively).

distinguish definitively the effect of tobacco exposure before and after pregnancy. However, considering both the relatively short time of pregnancy and the large difference of risk between the two exposed groups, we suggest that exposure to tobacco during pregnancy has more influence on asthma than tobacco exposure after pregnancy.

In summary, in a sub-sample of the Isle of Wight cohort, the combined effect of exposure to tobacco smoke during pregnancy and the common haplotype pair of the IL13 gene resulted in an increased relative risk of early-onset per- sistent wheeze and asthma. For tobacco smoke exposure later in childhood we did not observe this association. The IL13 gene did not pose a risk in its own right. These results demonstrate that the association between exposures to environmental risk factors, like tobacco smoke, can be modified by gene polymorphisms. Given that there are various patterns and prevalences of exposure to tobacco smoke in different populations, this study suggests that negative reports of genetic association studies may be due to differences in environmental exposures. We propose that the next step in the investigation of the interaction 
between IL13 and exposure to tobacco smoke is to examine the influence of ETS exposure on IL13 expression.

\section{Authors' contributions}

AS and WK designed the current study and conducted the analyses. SHA established the birth cohort and performed the clinical study. SHA and RK performed wheezing phenotypes analysis. MH aided on statistical analysis. SE performed the genetic analysis. All authors contributed in writing the manuscript and approved the final version.

\section{Acknowledgements}

This study was funded by the National Institutes of Health ROIAI06 I 47 I. The Isle of Wight birth cohort has been supported by grants from the Isle of Wight Health Authority Trust funds and Asthma UK. The authors would like to thank Dennis Shubitowski for technical assistance, Dr. Hans Cheng for providing access to the PSQ-96 instrument, and Susan Davis for her comments on the manuscript.

\section{References}

I. Woolcock AJ, Peat JK: Evidence for the increase in asthma worldwide. Ciba Found Symp 1997, 206:122-34; discussion 134-9, I57-9.

2. Moshammer H, Hoek G, Luttmann-Gibson H, Neuberger MA, Antova T, Gehring U, Hruba F, Pattenden S, Rudnai P, Slachtova H, Zlotkowska R, Fletcher T: Parental smoking and lung function in children: an international study. Am J Respir Crit Care Med 2006, I 73(II): I255-I263.

3. Jaakkola Jj, Gissler M: Maternal smoking in pregnancy, fetal development, and childhood asthma. Am J Public Health 2004, 94(I): 136-140.

4. Milner AD, Marsh MJ, Ingram DM, Fox GF, Susiva C: Effects of smoking in pregnancy on neonatal lung function. Arch Dis Child Fetal Neonatal Ed 1999, 80(I):F8-14.

5. Hoo AF, Henschen M, Dezateux C, Costeloe K, Stocks J: Respiratory function among preterm infants whose mothers smoked during pregnancy. Am J Respir Crit Care Med 1998, 1 58(3):700-705.

6. Brown RW, Hanrahan JP, Castile RG, Tager IB: Effect of maternal smoking during pregnancy on passive respiratory mechanics in early infancy. Pediatr Pulmonol 1995, 1 9(I):23-28.

7. Hanrahan JP, Tager IB, Segal MR, Tosteson TD, Castile RG, Van Vunakis $\mathrm{H}$, Weiss ST, Speizer FE: The effect of maternal smoking during pregnancy on early infant lung function. Am Rev Respir Dis 1992, I 45(5): I I 29- I I 35.

8. Weiss ST, Tager IB, Munoz A, Speizer FE: The relationship of respiratory infections in early childhood to the occurrence of increased levels of bronchial responsiveness and atopy. Am Rev Respir Dis 1985, I 3 I (4):573-578.

9. Wills-Karp M, Luyimbazi J, Xu X, Schofield B, Neben TY, Karp CL, Donaldson DD: Interleukin-13: central mediator of allergic asthma. Science (New York, NY 1998, 282(5397):2258-226I.

10. Zhu Z, Homer RJ, Wang Z, Chen Q, Geba GP, Wang J, Zhang Y, Elias JA: Pulmonary expression of interleukin- 13 causes inflammation, mucus hypersecretion, subepithelial fibrosis, physiologic abnormalities, and eotaxin production. J Clin Invest 1999, 103(6):779-788

II. Noakes PS, Holt PG, Prescott SL: Maternal smoking in pregnancy alters neonatal cytokine responses. Allergy 2003, 58(10): 1053-1058.

12. Feleszko W, Zawadzka-Krajewska A, Matysiak K, Lewandowska D, Peradzynska J, Dinh QT, Hamelmann E, Groneberg DA, Kulus M: Parental tobacco smoking is associated with augmented IL13 secretion in children with allergic asthma. J Allergy Clin Immunol 2006, II 7(1):97-102.

13. Colilla S, Nicolae D, Pluzhnikov A, Blumenthal MN, Beaty TH, Bleecker ER, Lange EM, Rich SS, Meyers DA, Ober C, Cox N]: Evidence for gene-environment interactions in a linkage study of asthma and smoking exposure. J Allergy Clin Immunol 2003, I I I (4):840-846.
14. Meyers DA, Postma DS, Stine OC, Koppelman GH, Ampleford EJ, Jongepier H, Howard TD, Bleecker ER: Genome screen for asthma and bronchial hyperresponsiveness: interactions with passive smoke exposure. J Allergy Clin Immunol 2005, II5(6): I I69-1 I75.

15. Wang Z, Chen C, Niu T, Wu D, Yang J, Wang B, Fang Z, Yandava CN, Drazen JM, Weiss ST, Xu X: Association of asthma with beta(2)adrenergic receptor gene polymorphism and cigarette smoking. Am J Respir Crit Care Med 200I, 163(6): I 404-I 409.

16. Kabesch M, Hoefler C, Carr D, Leupold W, Weiland SK, von Mutius E: Glutathione $S$ transferase deficiency and passive smoking increase childhood asthma. Thorax 2004, 59(7):569-573.

17. Sadeghnejad A, Meyers DA, Bottai M, Sterling DA, Bleecker ER, Ohar JA: ILI 3 Promoter Polymorphism - I I 2C/T Modulates the Adverse Effect of Tobacco Smoking on Lung Function. Am J Respir Crit Care Med 2007.

18. van der Pouw Kraan TC, van Veen A, Boeije LC, van Tuyl SA, de Groot ER, Stapel SO, Bakker A, Verweij CL, Aarden LA, van der Zee JS: An IL-13 promoter polymorphism associated with increased risk of allergic asthma. Genes Immun I999, I(I):6I-65.

19. Vladich FD, Brazille SM, Stern D, Peck ML, Ghittoni R, Vercelli D: ILI3 RI30Q, a common variant associated with allergy and asthma, enhances effector mechanisms essential for human allergic inflammation. J Clin Invest 2005, I I 5(3):747-754.

20. Leung TF, Tang NL, Chan IH, Li AM, Ha G, Lam CW: A polymorphism in the coding region of interleukin- 13 gene is associated with atopy but not asthma in Chinese children. Clin Exp Allergy 200I, 3 I(10):I5I5-I52I.

21. Hakonarson $\mathrm{H}, \mathrm{W}$ jst $\mathrm{M}$ : Current concepts on the genetics of asthma. Current opinion in pediatrics 200 I, 13(3):267-277.

22. Devereux G, Barker RN, Seaton A: Antenatal determinants of neonatal immune responses to allergens. Clin Exp Allergy 2002, 32(I):43-50.

23. Kurukulaaratchy RJ, Fenn MH, Waterhouse LM, Matthews SM, Holgate ST, Arshad SH: Characterization of wheezing phenotypes in the first 10 years of life. Clin Exp Allergy 2003, 33(5):573-578.

24. Sadeghnejad A, Karmaus W, Davis S, Kurukulaaratchy RJ, Matthews $\mathrm{S}$, Arshad SH: Raised cord serum immunoglobulin $E$ increases the risk of allergic sensitisation at ages 4 and 10 and asthma at age 10. Thorax 2004, 59(I I):936-942.

25. SNPper: The Children's Hospital Informatics Program (CHIP) Bioinformatics Tools. Harvard school of medicine (Boston, MA). 2005 [http://snpper.chip.org]

26. Tarazona-Santos E, Tishkoff SA: Divergent patterns of linkage disequilibrium and haplotype structure across global populations at the interleukin-I3 (ILI3) locus. Genes Immun 2005, 6(I):53-65.

27. Donfack J, Schneider DH, Tan Z, Kurz T, Dubchak I, Frazer KA, Ober $C$ : Variation in conserved non-coding sequences on chromosome $5 q$ and susceptibility to asthma and atopy. Respiratory research 2005, 6: 145

28. Hoffjan S, Ostrovnaja I, Nicolae D, Newman DL, Nicolae R, Gangnon R, Steiner L, Walker K, Reynolds R, Greene D, Mirel D, Gern JE, Lemanske RF Jr., Ober C: Genetic variation in immunoregulatory pathways and atopic phenotypes in infancy. J Allergy Clin Immunol 2004, I I3(3):5 I I-5 I8.

29. Howard TD, Whittaker PA, Zaiman AL, Koppelman GH, Xu J, Hanley MT, Meyers DA, Postma DS, Bleecker ER: Identification and association of polymorphisms in the interleukin- 13 gene with asthma and atopy in a Dutch population. Am J Respir Cell Mol Biol 200I, 25(3):377-384

30. Hummelshoj T, Bodtger U, Datta P, Malling HJ, Oturai A, Poulsen LK, Ryder LP, Sorensen PS, Svejgaard E, Svejgaard A: Association between an interleukin-13 promoter polymorphism and atopy. Eur J Immunogenet 2003, 30(5):355-359.

31. Puthothu B, Krueger M, Forster J, Heinzmann A: Association between severe respiratory syncytial virus infection and ILI3/IL4 haplotypes. The Journal of infectious diseases 2006, 193(3):438-44I.

32. Barrett JC, Fry B, Maller J, Daly MJ: Haploview: analysis and visualization of LD and haplotype maps. Bioinformatics 2005, 21(2):263-265.

33. Hill WG, Robertson A: The effect of linkage on limits to artificial selection. Genet Res 1966, 8(3):269-294. 
34. Stephens M, Smith NJ, Donnelly P: A new statistical method for haplotype reconstruction from population data. Am J Hum Genet 200I, 68(4):978-989.

35. Pattaro C, Heinrich J, Werner M, de Marco R, Wjst M: Association between interleukin- $I$ receptor antagonist gene and asthmarelated traits in a German adult population. Allergy 2006, 6I(2):239-244.

36. Peters U, Chatterjee N, Yeager M, Chanock SJ, Schoen RE, McGlynn KA, Church TR, Weissfeld JL, Schatzkin A, Hayes RB: Association of genetic variants in the calcium-sensing receptor with risk of colorectal adenoma. Cancer Epidemiol Biomarkers Prev 2004, I3(I 2):2|8|-2|86.

37. Kurukulaaratchy RJ, Waterhouse L, Matthews SM, Arshad SH: Are influences during pregnancy associated with wheezing phenotypes during the first decade of life? Acta Paediatr 2005, 94(5):553-558.

38. Graves PE, Kabesch M, Halonen M, Holberg CJ, Baldini M, Fritzsch C, Weiland SK, Erickson RP, von Mutius E, Martinez FD: A cluster of seven tightly linked polymorphisms in the IL- I 3 gene is associated with total serum IgE levels in three populations of white children. J Allergy Clin Immunol 2000, I05(3):506-5I3.

39. Bottini N, Borgiani P, Otsu A, Saccucci P, Stefanini L, Greco E, Fontana L, Hopkin JM, Mao XQ, Shirakawa T: IL-4 receptor alpha chain genetic polymorphism and total IgE levels in the English population: two-locus haplotypes are more informative than individual SNPs. Clinical genetics 2002, 6I(4):288-292.

40. Wilson JN, Rockett K, Jallow M, Pinder M, Sisay-Joof F, Newport M, Newton J, Kwiatkowski D: Analysis of ILI 0 haplotypic associations with severe malaria. Genes Immun 2005, 6(6):462-466.

41. Sadeghnejad A, Karmaus W, Hasan Arshad S, Ewart S: ILI3 gene polymorphism association with cord serum immunoglobulin E. Pediatr Allergy Immunol 2007, I 8(4):288-292.

42. Cameron L, Webster RB, Strempel JM, Kiesler P, Kabesch M, Ramachandran H, Yu L, Stern DA, Graves PE, Lohman IC, Wright AL Halonen M, Klimecki WT, Vercelli D: Th2 cell-selective enhancement of human IL I 3 transcription by IL I $3-$ I I I 2C > T, a polymorphism associated with allergic inflammation. J Immunol 2006, I77( ( 2):8633-8642.

43. Vercelli D: Learning from discrepancies: CDI4 polymorphisms, atopy and the endotoxin switch. Clin Exp Allergy 2003, 33(2): $153-155$.

44. Liu X, Beaty TH, Deindl P, Huang SK, Lau S, Sommerfeld C, Fallin MD Kao WH, Wahn U, Nickel R: Associations between total serum IgE levels and the 6 potentially functional variants within the genes IL4, ILI 3, and IL4RA in German children: the German Multicenter Atopy Study. J Allergy Clin Immunol 2003, I I 2(2):382-388

\section{Publish with Bio Med Central and every scientist can read your work free of charge}

"BioMed Central will be the most significant development for disseminating the results of biomedical research in our lifetime. "

Sir Paul Nurse, Cancer Research UK

Your research papers will be:

- available free of charge to the entire biomedical community

- peer reviewed and published immediately upon acceptance

- cited in PubMed and archived on PubMed Central

- yours - you keep the copyright
BioMedcentral 